\title{
Le moulin hydraulique à conduites forcées de Karapinar (Turquie)
}

\section{Serge Sadler}

\section{(2) OpenEdition}

1 Journals

Édition électronique

URL : https://journals.openedition.org/tc/803

DOI : $10.4000 /$ tc. 803

ISSN : 1952-420X

Éditeur

Éditions de l'EHESS

\section{Édition imprimée}

Date de publication : 1 juin 1989

ISSN : 0248-6016

\section{Référence électronique}

Serge Sadler, « Le moulin hydraulique à conduites forcées de Karapinar (Turquie) », Techniques \& Culture [En ligne], 12। 1989, mis en ligne le 16 janvier 2006, consulté le 29 septembre 2022. URL : http://journals.openedition.org/tc/803 ; DOI : https://doi.org/10.4000/tc.803

Ce document a été généré automatiquement le 29 septembre 2022.

Tous droits réservés 


\section{Le moulin hydraulique à conduites forcées de Karapinar (Turquie)}

Serge Sadler 